$\mathrm{Oz}$

$1-1-1990$

\title{
The Writing of Architecture: Mnemosyne and the Wax Tablet
}

Jeffrey Hildner

Follow this and additional works at: https://newprairiepress.org/oz

\section{c) (1) $\Theta($}

This work is licensed under a Creative Commons Attribution-Noncommercial-No Derivative Works 4.0 License.

\section{Recommended Citation}

Hildner, Jeffrey (1990) "The Writing of Architecture: Mnemosyne and the Wax Tablet," Oz: Vol. 12.

https://doi.org/10.4148/2378-5853.1190

This Article is brought to you for free and open access by New Prairie Press. It has been accepted for inclusion in Oz by an authorized administrator of New Prairie Press. For more information, please contact cads@k-state.edu. 


\section{The Writing of Architecture: Mnemosyne and the Wax Tablet}

Jeffrey Hildner

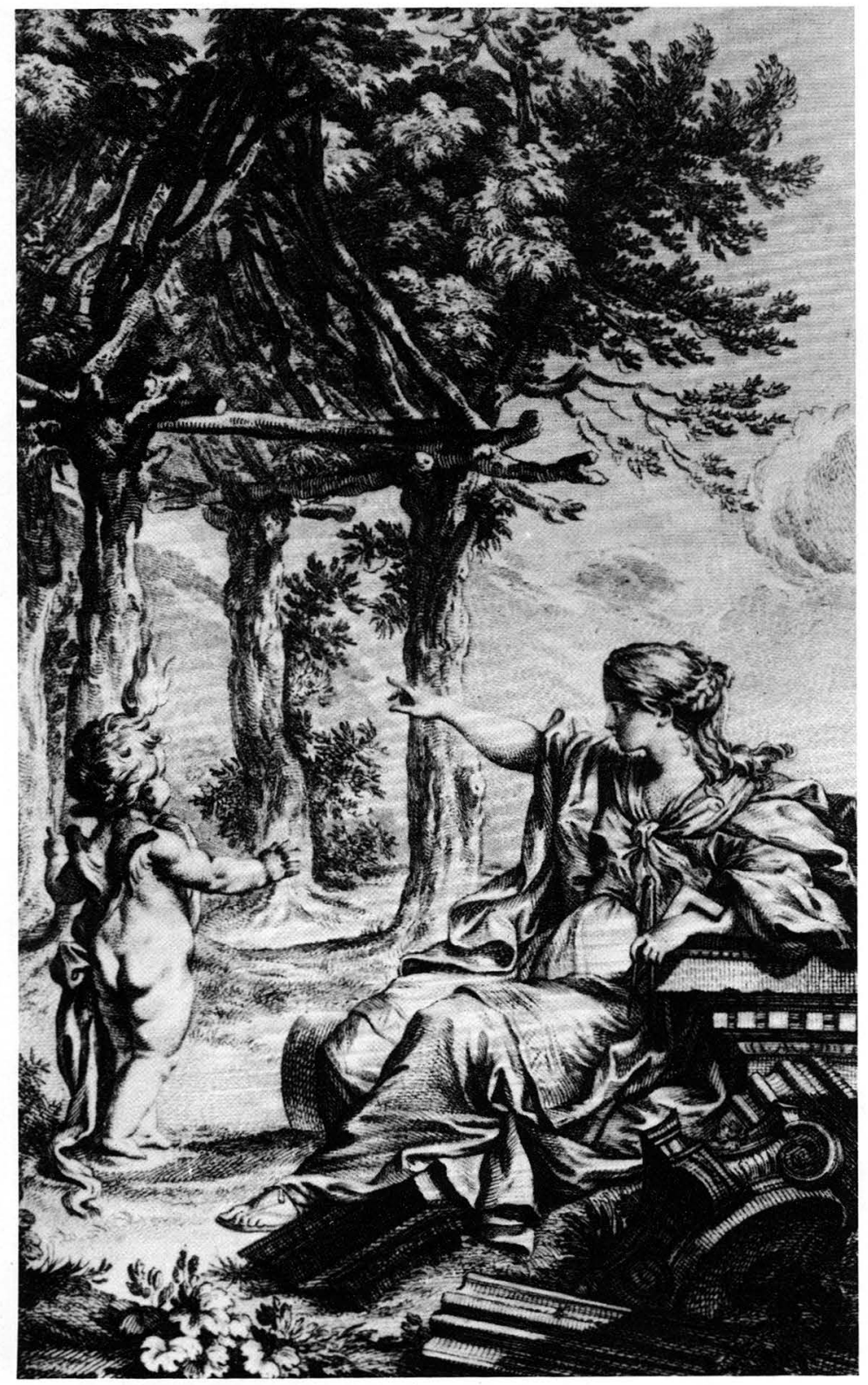

1. Mnemosyne (?) Origins; from the frontispiece to the second edition of MarcAntoine Laugier's Essai sur l'architecture, 1755
The concomitant sensations awakened in us by the direct perception of a work of art ... are only realized through memory. Memory therefore 'does not assume in art a subsidiary or ancillary function as happens in normal life, but is, itself, Art, in which all the various arts are united without residua. Ancient mythology saw this clearly, in a way, when it imagined that Mnemosyne was the mother of the Muses.'

- Antonio Russi ${ }^{1}$

In the search for nature - for the "true" origin and order of things - we will find in architecture the origins of memory and the invention of culture. Architecture is the resistance to forgetfulness. ${ }^{2}$ She is the Text of Memory "'each buman thought, bas its pages in this vast book [of arcbitecture]" )', the writing of the past, the present, and the future: the "wax writing-tablet" upon which are impressed the "images" of history. ${ }^{4}$

\section{Memory is Architecture \\ Past}

It was required that a small study be added to a gardener's cottage at the brook's edge on a private estate and that it be in keeping with the rustic context established by the existing vernacular buildings and pastoral landscape. I decided on an architecture that might be a contemplation and memory of "the home of the first man," ${ }^{5}$ the primitive hut, as represented in the frontispiece to the second edition of Marc-Antoine Laugier's Essai sur l'arcbitecture of 1755 . In this canonical image of architecture's mythic origins, a woman seated amidst broken fragments of classical architecture gestures with apparent graceful authority to the primitive hut's idealized (re)construction formed in accordance with "principles ... founded on simple nature." Four trees are columns; four branches are beams; branches above "inclining towards each other, meet at their highest point" (Laugier 12) and form a roof terminating in triangular openings at two ends (a differentiation of the otherwise equal four sides - or quadripartite space - which we may say constitutes the "original" example of formal hierarchy)

As is widely recognized, Laugier's simple "first" architecture, innocent as it may appear, was the basis for what was considered a startling - essentially antiRenaissance - manifesto when the essay was first issued anonymously in 1753 , sans illustration. Whereas Vitruvius (and commentators of Vitruvius, such as Perrault in the seventeenth century) had set forth the idea of the rustic hut as the prototype from which all architecture has evolved, Laugier was not content with a merely dispassionate acknowledgment of the hut's rudimentary historical role. For Laugier, a Jesuit priest, the hut also assumed pragmatic meaning and ontological, as well as typological, significance. The primitive hut was to be the operative model for all present and future architectural excellence; and, by a return to the past, to architecture's (putative) 
origins in Nature - in "natural" form -, it represented the means whereby architectural morality might be revived and historical continuity sustained? As an intrinsic part of his fundamentally rationalist agenda, Laugier asserted that classicism (in which we see trabeation canonized as the root system of architecture) is the authentic, albeit sophisticated, descendant of the "primitive" hut. Thus from his narrative reconstruction of mankind's creation of the primordial building (Laugier 11-12), to which he gave indissoluble mental presence through the allegorical visibilia of his frontispiece, Laugier argued for a reductivist, neoclassical language which "in an architec tural Order only the [free-standing] column, the entablature and the pedimen [these are the identifiable fragments in the foreground of the frontispiece - the broken architrave being clearly intended to represent the pediment which it typically surrounds] may form an essen tial part" (Laugier 12; emphasis added) The rational tectonic of these three elements - the walls of the Renaissance having yet to be born - we may regard as
Laugier's remembrance of origins.

Significantly, however, with regard to the fundamental philosophical question of the structure of architecture's relationship to nature to which his manifesto is principally intellectually directed, Laugier's "remembrance" is inherently paradoxical. His frontispiece is a true representation of neither nature nor culture: trees do not "naturally" grow foursquare in plan; and whereas his archetype "has not .. even ceased to be 'nature', inasmuch as the upright members [trees] are still rooted in the earth" (McClung 118), 8 it is the primary attribute of the simulacra to which it has in theory given rise (i.e., all architectures) that they have, indeed, ceased to be nature. Architecture is, fundamentally, the cessation of nature; it is defined as (and defines) the presence of culture. Laugier's manifest intention to pictorially (con)fuse the point where nature stops and culture (art) begins (a point which his text delineates with less ambiguity) recalls a passage from Tasso's epic poem, Gerusalemme liberata: "Art, which does everything, remains hidden.
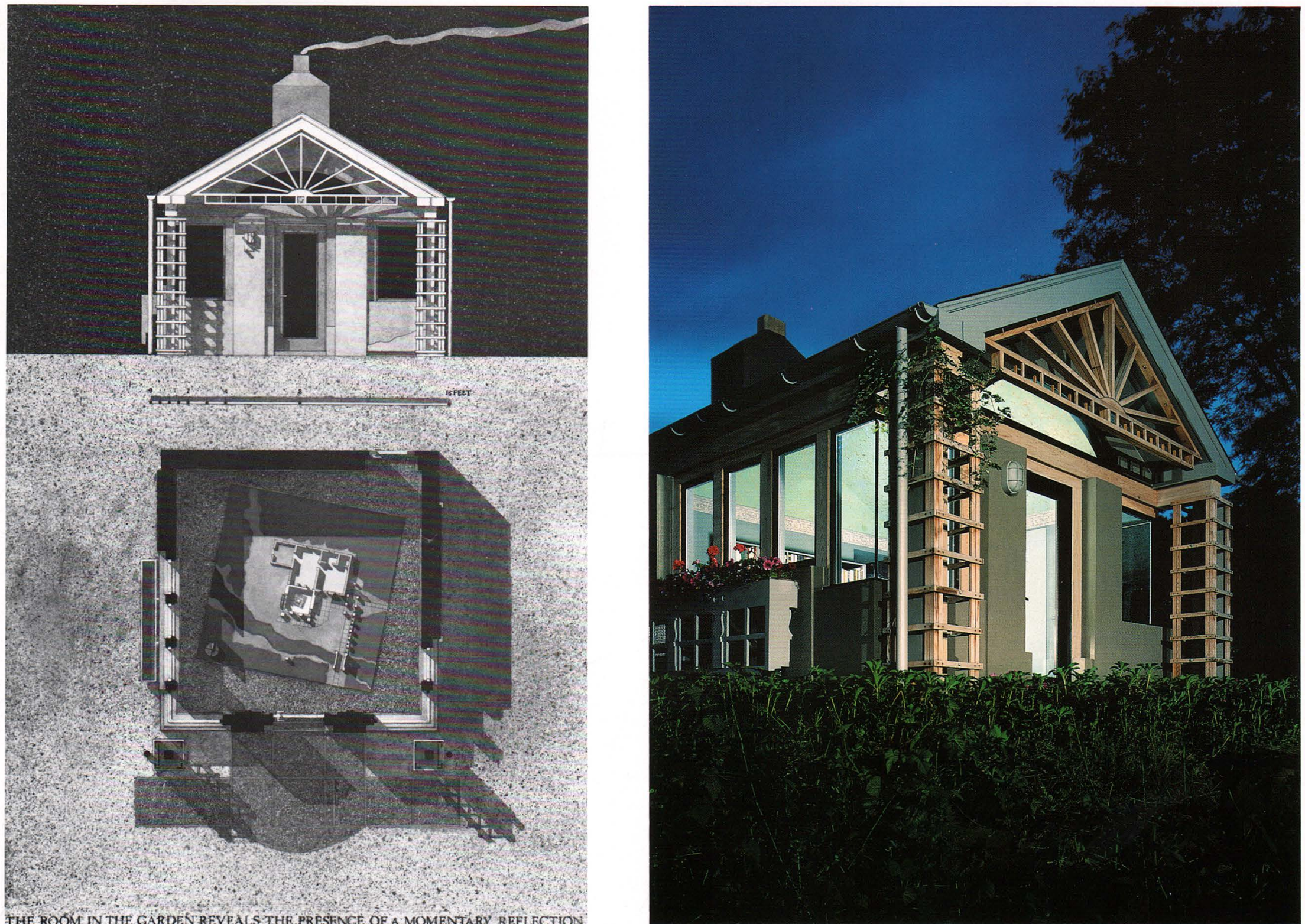
There is such a mixture of culture ... that you imagine that the ornaments and the arrangements are only natural. It seems as if nature were playing at imitating her own imitator, art" (Praz 229)?

Perhaps it is to the nature/culture paradox (which is central to the problem of architecture's metaphysic) that we may largely attribute the subliminal power of the primitive hut as Laugier has depicted it - specifically, a pitched roof volume (ideally comprised of the essential tripartite syntax) - to operate in architectural consciousness with unique dialectical resonance: possessed of a mythicized "presumption of innocence,"10 it is the iconic expression of a deeply entrenched, traditional image of shelter from which an advanced architecture usually seeks to depart but may sometimes remember, as in a momentary reflection. Correlatively, the idea of the primitive hut, separate from the image of its specific form or elements, independent of a preconceived typological guise, operates as a unique metaphor for renewal and rethinking, as an ever present reminder to return to a contemplation of architecture's cosmology and the problem of origins. ${ }^{11}$

In this regard, Laugier's frontispiece invites a second level of meaning. If the primitive hut represents the origin of architecture, I think that it also represents the origin of memory. ("Architecture ... [we] may live without ber ... but we cannot remember without her" [Ruskin 182]). The frontispiece may be interpreted as illustrating not only the image of architecture's origin but the moment of architecture's origin as well and, consequently, as illustrating the coincident moment of the inception of historical consciousness and the (initial) enactment of culture. It is a picture of time as well as of typology.

Reflection on the significance of the presence of the female figure who appears to preside over the mise-en-scene suggests a line of thought that helps to give poetic sustenance to this idea, I believe. The

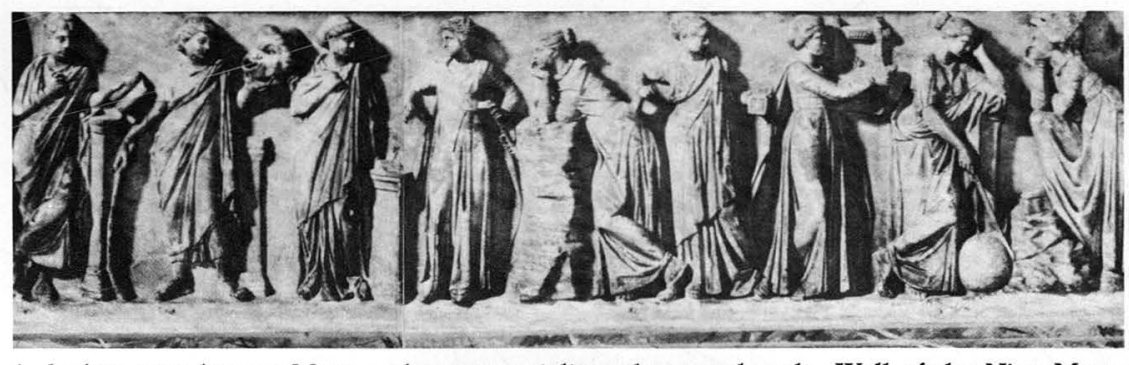

4. Architecture has no Muse ... but memorializes the arts that do. Wall of the Nine Muses ("Reminders"), daughters of Mnemosyne

generally held to be a personification of architecture, referred to, variously, as "the personification of architecture," "the god dess Architectura," and "the muse." ${ }^{12}$ While it seems fairly clear that this woman who holds in her left hand a compass and square is, indeed, a goddess of architecture, it is also likely that, significantly, she is a deity with no history. Perhaps, then, we may bring to this goddess the greater historical and metaphysical dimension - if not the greater believableness - which her presence at this original "first" moment in the chronology of culture requires of her. Perhaps, in a renewal of the Renaissance tradition, we may (re)invent her identity, attach her to a deity already in existence, and in this manner bring to the temporal and symbolic limitations of her neoclassical iconography the validation of a rich, classical Greek past. Perhaps we may think of her as Mnemosyne, Memory herself.

According to classical mythology, Mnemosyne (ni.mäs'e.enē), the goddess of Memory, or Remembrance, ("as monuments go to show and, indeed, the impression left by the name in the minds of men,")13 was either a Titaness born of Uranus (Heaven) and Gaea (Earth) or a pure abstraction, memory personified a principle, whose presence was considered essential for the establishment of the world. In the early stages of the Greek theogony there was no god of time; the continuity of the world was guaranteed by

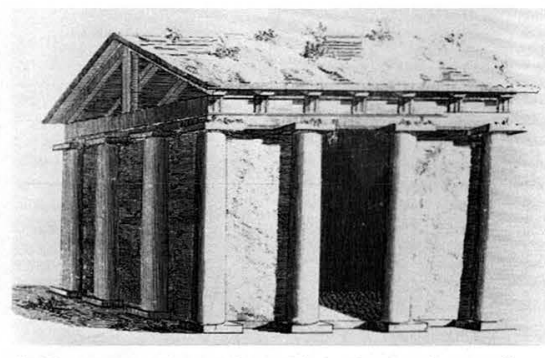

5. Primitive hut after Chambers: the wall a nonfigurative and secondary

Mnemosyne (Grimal 103). She was held to be the basis of all life and creativity (forgetfulness - especially of the "true order and origin of things" - was considered tantamount to death) ${ }^{14}$ Moreover, Mnemosyne was the Mother of the Muses - the Nine "Reminders" - who were the deific personifications of, and sources of inspiration for, the Arts. Like Mnemosyne, her daughter Muses served as forces of culture, refinement, and civilization, towards the end that man might be enabled to rise above mere banality in his artistic and intellectual aspirations. ${ }^{15}$ However, while Muses were assigned to poetry, music, and dance (as well as to astronomy and history), no Muse was assigned to architecture or the other "fine arts." This may have been

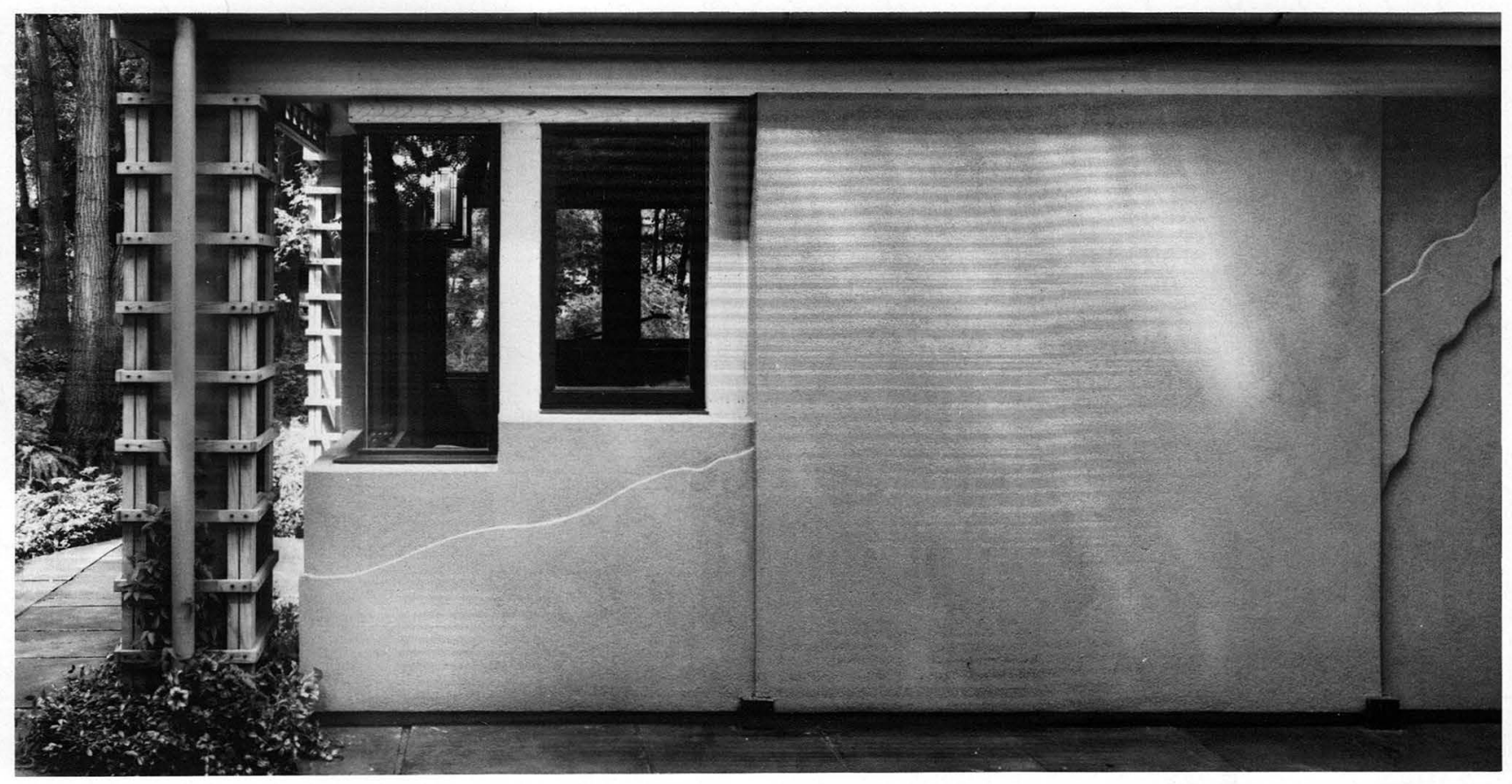

6. East elevation. The wall as event, figurative and primary: painterly surface and contemplative object, inscribing both the memory of nature (water and smoke) and the presence of geometric abstraction; the analogical "wax writing-tablet" 
because architecture, painting, and sculpture were possibly, ironically, undervalued in Greece and Rome; or perhaps they had a more direct relationship with Mnemosyne herself. ${ }^{16}$ In the Renaissance, nonetheless, the fine arts were considered the supreme arts largely because they were perceived to have flourished among, and to have been highly honored by, the ancients, especially the Romans; and what seems to have been a matter of some debate is whether architecture is a sister art or mother of the arts. ${ }^{17}$

Alberti thought of architecture as the "art of arts, the queen and sum of all the others" (Borsi 14). If Mnemosyne (Memory) is the Mother of the Muses (Arts) and Architecture is the Mother of the Arts, may we not make the poetic leap, then, that Memory and Architecture are one? And, therefore, that if "memory is the necessary condition for the existence of the arts" (McClung 148), that architecture (memory made immanent) is the necessary condition for the existence of the arts? It seems, I believe, that we have a genuine basis for paraphrasing Russi and declaring that Memory is Architecture.

\section{The (re)Enactment of Memory Present}

As with the small project seen here, every architecture is attended by the same goddess of Memory who first attended its creation and breathed life into its form. Whether that form derives literally from Laugier's primitive hut, as here, or from the form of Alberti's "things as yet unseen and unheard of" (Borsi 13), every act of architecture is a sacred breaking away from nature to culture, of which memory is the historian.

This new primitive hut is built on the foundation of a greenhouse formerly attached to the cottage. It is a remembrance of the greenhouse, of the simple gabled form and associations with nature that it shares with the primitive hut. The painted window box, the cedar lattice-columns, and the cedar fan-truss pediment are ar- chitectural as well as garden elements: they are the physical and psychological mediators between nature and culture, between the presence of the garden, un intruded upon, and the presence of architecture, unsentimentalized. The lattice-columns are "trees," but unlike the original primitive hut they are products of culture, not nature. Each surrounds a structural wood post which carries the roof load and allows the modernist expression of a dematerialized (glass) corner as read on the east and west walls.

As the word template suggests, the word temple originally derives from the idea of being "cut-out-from." Thus, the first temple, the primitive hut, is the sacred space that man cut-out-from the profane space of the world around him, the "revelation of an absolute reality, opposed to the nonreality of the vast surrounding expanse," of which Mircea Eliade writes. ${ }^{18}$

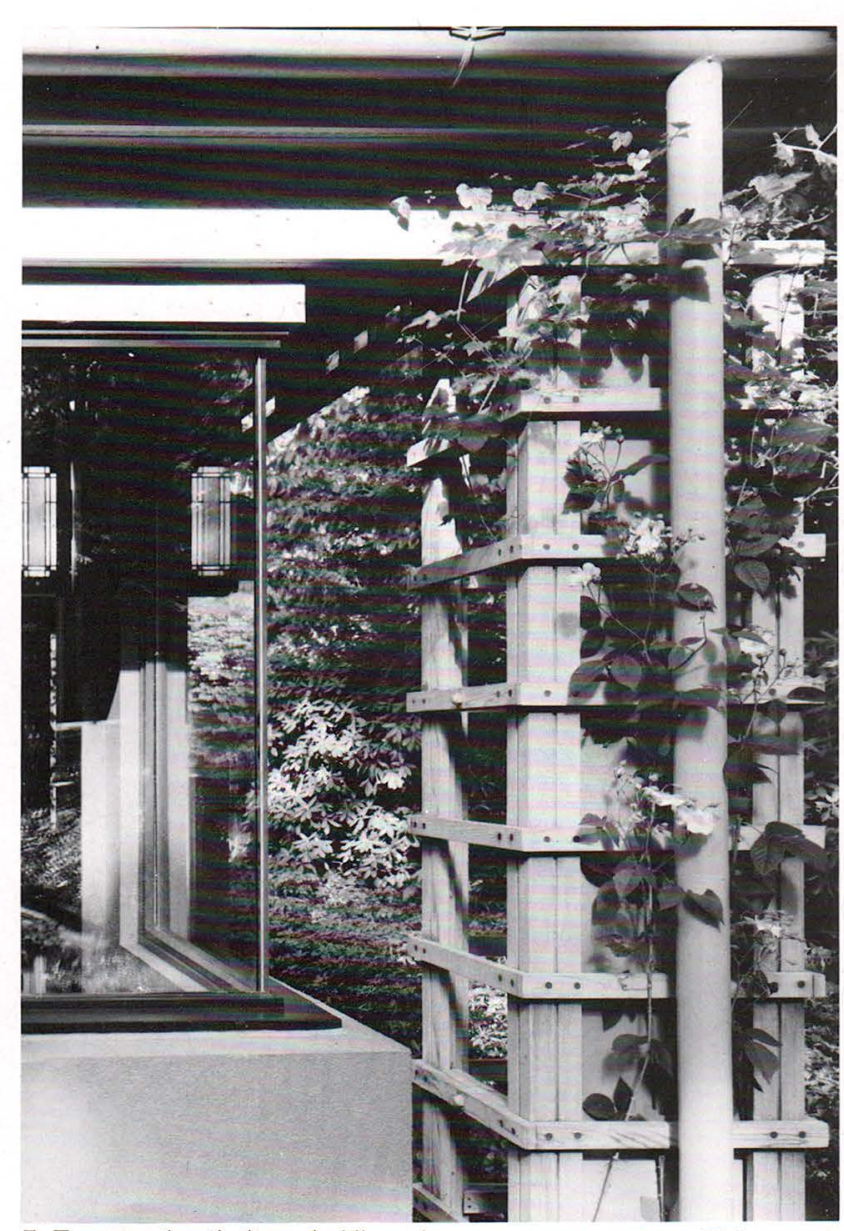

7. Exterior detail, diptych. The column as surrogate tree: "It is never the thing but the version of the thing ..." (Wallace Stevens)
The temple, the symbol or paradigm of all architecture, is the place of contemplation (con-temple-ation). But the absence of walls allows the original primitive hut to do no more than merely delimit the precinct of sacred space: the act of definitive enclosure and the mature presence of the dialectical phenomenology of interior versus exterior is a later invention ("soon [man] will fill in the space between two posts and feel secure" [Laugier 12]). As McClung writes, "What is not implied by the three structural elements [column, entablature, and pediment], such as a wall, is tolerated [only] if it fulfills minimally necessary functions and without flourish" (118). In this project, the (interior) room and the wall are intended as primary architectural events

The interior ceiling is rendered a faux oxidized copper, a decorative act of inver- sion or transparency whereby the copper roof, which is typically outside, becomes, now visible from within, the surrogate celestial vault. The motives of the tradi tional plaster molding make reference to nature. The wall and ceiling light fixtures - black ash, mother-of-pearl inlay, and stained glass - are remembrances of culture, to which the architectural and decorative arts traditions belong (here as inspired mainly by Mackintosh and Wright).

Along the face of the exterior stucco canvas I have drawn the brook. Its painterly irregularity of line is also a reference to the smoke of the chimney. The movement of line and allusion to nature are super imposed on the stillness of a geometric order. The delineation of the wall surface is intended as a circumstantial, personal expression in opposition to the iconic, universal image of the pedimented 
volume. The blind square stucco panel is "supported" by two marble cubes. The square and the cube are symbols of the perfection of man, the inventor of culture and the "imaginator" of mathematical abstractions. Here the square interrupts the drawing of the brook and is the place of visual and mental rest - the place for the superimposition of the writing of the mind - as well as the center of the intended entrance procession. The wall and the interior room of which it is the face are part of an architecture which has its origins in the cultural inventions of drawing, painting, decoration, and geometric abstraction. This is in dialectical opposition to the simple tectonic of the original "wall-less" primitive hut which had yet to include the musings of the other arts.

\section{The Text of Architecture Future}

One of the attributes of Mnemosyne is that she knows everything - past, present, and future. Memory, then, includes within it both the traditional idea of "remembrance of the past" as well as the "reminder" to create the future, and this apprehension of historical continuum constitutes our memory of the present. ${ }^{19}$ The memory of the past, present, and future is the genuine Text of Architecture.

In making architecture, memory of what has gone before, of the past (history), is in dialectical confrontation with newness, invention, with the as-yet-unapprehended-to-be. Memory is both part of that newness and separate from it, the "custodian" of invention and the impediment to it, both the "treasure-house" "Now let us turn to the treasure-house of inventions . memory" [Yates 5]) and the chains. Similar to writers, architects draw from the repositories of their imaginations on both the familiar and the unfamiliar (the newly invented) texts of memory.

We are writers. We write buildings instead of books (perhaps in addition to books). We author (authorize/give authority to) architecture. We contribute steel volumes literature of architecture. Not unlike the Egyptians whose temples were virtually illuminated manuscripts of stone, or the Medieval Masons whose cathedrals were "book[s] to be read and understood ... for there is history in them" (Proust; Frank 124), we, unavoidably, (re)write the text of architecture (memory) on the pages of our own constructional inventions. ${ }^{20}$

\section{Mnemosyne (?)}

We may apprehend Laugier's frontispiece then, to be an allegory of the origins of architecture, memory, and culture. Mnemosyne (Memory), "the symbolic representation of mental order," ${ }^{21}$ is authoring (and being authored by) the origin of Architecture. If Architecture and Memory are both abstractions, then the primitive hut is their emblematic constructional expression and the goddess is their emblematic personified expression (Architec turalMnemosyne). The intersection of the hand and the column, on the horizon line of the eye and mind (at the geometric

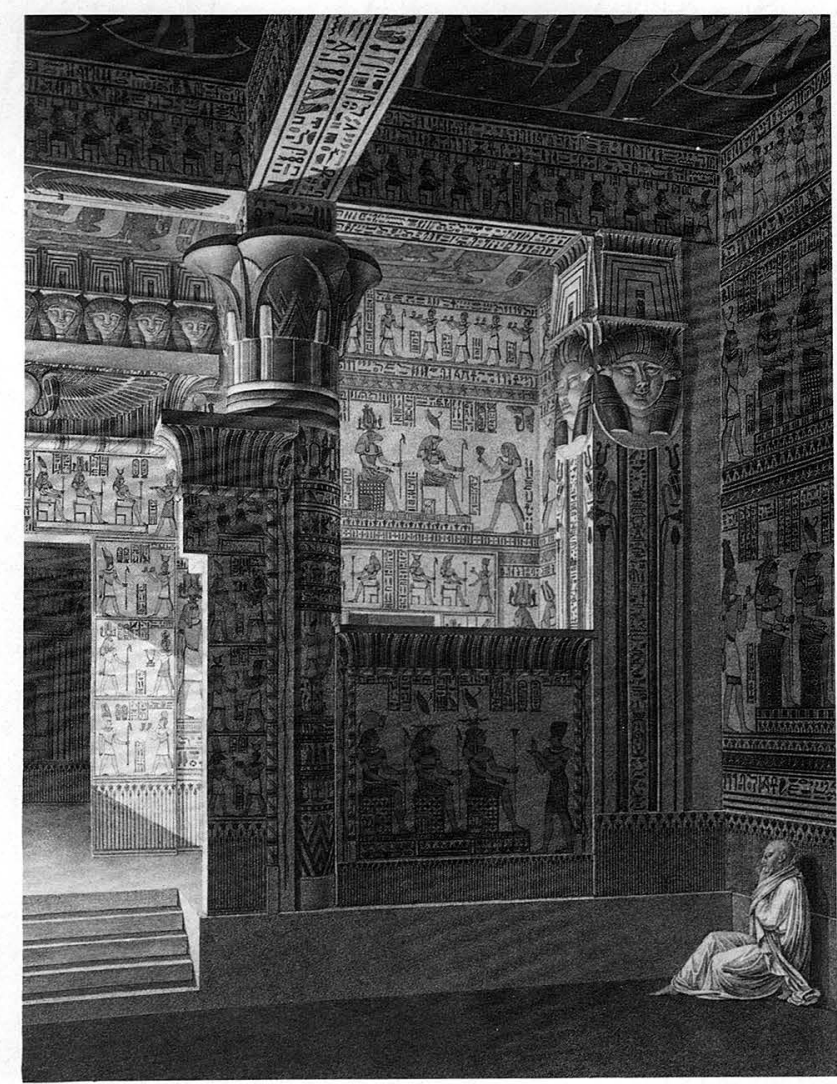

10. Manuscript of stone: architecture as the writing of collective memory. Interior of the west temple. Memnonium, Thebès

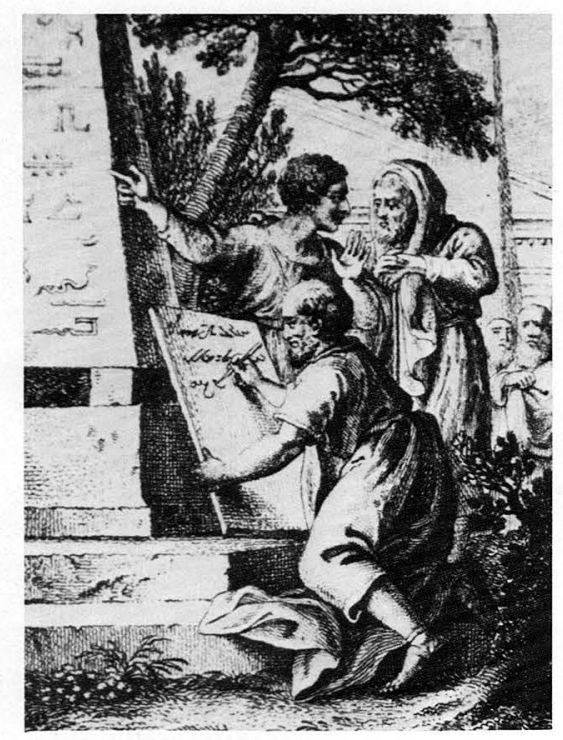

9. Allegory of the invention of writing from monuments (architecture/memory)

center of vision and consciousness), symbolizes the moment of the mutual origination of architecture and memory. Memory writes on the wax-tablet of Architecture the origins of culture and the arts. ${ }^{22}$
NOTES

1. Mario Praz quotes Russi in Mnemosyne: The Parallel Between Literature and the Visual Arts (Princeton: Princeton University Press, 1970), 57.

2. "There are but two strong conquerors of the forgetfulness of men, Poetry and Architecture. and the latter in some sort includes the former. and is mightier in its reality." (John Ruskin, The Seven Lamps of Architecture [London: Everyman's Library, 1969], 182).

3. Victor Hugo, Notre-Dame de Paris, 2 vols. (New York: Booklover Press, s.d.), I: 211. See Narciso G. Menocal. "Louis Sullivan and Victor Hugo: Two Approaches to Reading Buildings," Via 8: Architecture and Literature (New York: Rizzoli, 1986), 71: "According to Hugo, architecture had been the most important repository of knowledge throughout the Middle Ages, but literature usurped that premier role with the invention of the printing press." Ellen Eve Frank illuminates this theme of the architecture/memory and literature interrelationship in the nineteenth century view of buildings (n. 2) in Literary Architecture: Essays Toward a Tradition - Walter Pater, Gerard Manley Hopkins, Marcel Proust, Henry James (Berkeley: University of California Press, 1979). Frank writes of architecture's memorial function, quoting Pater: "In that grandiose art of building ... there [are]

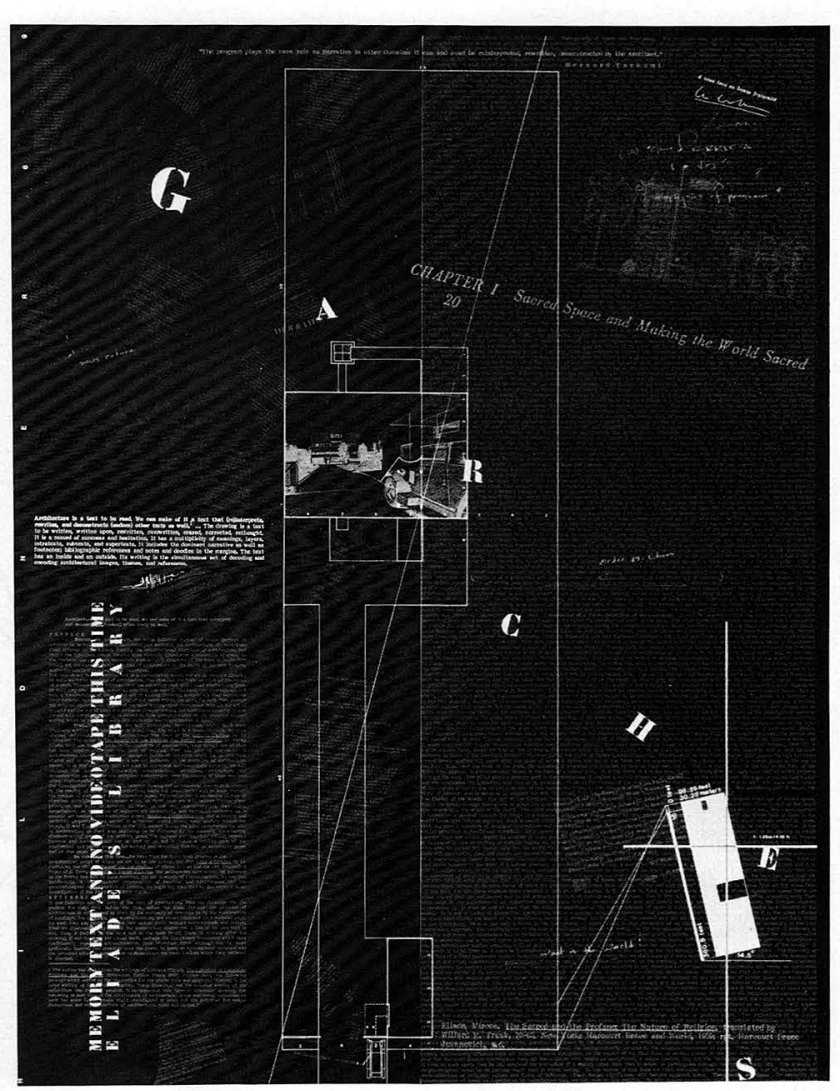

11. Site plan as text; program for a theoretical project: "Eliade's Library (On the Estate of the 'Ideal Villa')' 
historical documents hardly less clearly legible than the manuscript chronicle"'(34).

4. In the Greek ars memoria (art of memory) tradition which descended to Rome, architecture acted as a device for memory. Within the imagination, "images" (texts) wete deposited on "places" which were memorized in the building. When these rooms, walls, and other syntactic "place" elements were mentally revisited "the various deposits [were] demanded of their custodians;"' (Frances A. Yates, The Art of Memory [Chicago: The University of Chicago Press, 1966l, 3). According to Cicero, it was the poet Simonides who was the inventor of the art of memory when he used architecture as a mnemonic place system to identify the dead bodies in the banqueting hall from which he had propitiously absented himself prior to its collapse. Cicero's passage from De oratore, quoted in Quintilian's Institutio oratoria, is the most famous text wherein architecture is used as an analogue for memory/writing: "We require therefore places [architecture], either real or imaginary, and images [writing/text] or simulacra which must be invented ... so that as Cicero says, 'we shall employ the places and images respectively as a wax writing-tablet and the letters written on it."'(2). "The art of memory is like an inner writing" (Yates 6); architecture, therefore, is the wax writing-tablet and "custodian" of this inner writing, of memory.

5. Joseph Rykwert, On Adam's House in Paradise: The Idea of the Primitive Hut in Architectural History (New York: The Museum of Modern Art, 1972), 192.

6. Marc-Antoine Laugier, An Essay on Architecture, trans. Wolfgang Herrmann (Los Angeles: Hennessey \& Ingalls, Inc., 1977), 11.

7. See William Alexander McClung, The Architec ture of Paradise: Survivals of Eden and Jerusalem (Berkeley: University of California Press, 1983) and Robin Middleton and David Watkin Neoclassical and 19th. Century Arcbitecture (New York: Harry N. Abrams, Inc., 1980). "All the splendors of architecture ever conceived have been modeled on the little rustic hut ... It is by approaching the simplicity of this first mode that fundamental mistakes are avoided and true perfection is achieved" (Laugier 12). Laugier's aesthetic moralism, allied with French Primitivism, had as its not insignificant theological aim to "equate primitiveness with perfection, and ... suggest that material progress [has] no relevance to man's spiritual progress, which demand[s] only a constant reference to those natural virtues best exemplified in the past." Peter Collins, Changing Ideals in Modern Architecture 1750-1950 (Montreal: McGillQueen's University Press, 1965), 95.

8. While McClung correctly describes the rooted trees in Laugier's illustration (which man presumably either planted or stumbled upon [n. 12b]), the essay itself differs on this critical point regarding the "columns:" from among the "fallen branches in the forest," man "chooses four of the strongest" (Laugier 12; emphasis added)

9. The Laugierian hut (of the frontispiece) is clearly a fabrication, artifice, the imagination of the abbés acculturative mind and not an inevitable evolutionary product of "simple nature" at all. Laugier's concept that "by imitating the natura process, art was born" (Laugier 12) reflects the traditional privileging of nature over culture which has descended from Plato's idea mimesis wherein nature presents the ideal reality that art should "re-present." In the medieval esthetics of Aquinas, by way of contrast, reality and truth were thought to reside in the mind of the artist. Fidelity to the external world, to nature was not a fundamental artistic requirement. It is an aspect of Laugier's paradox, I believe, that he employs mimetic theory to support an idealized object which he arrived at in the Aquinian manner.

10. Terence Hawkes, Structuralism and Semiotics (Berkeley: University of California Press, 1977), 107. The idea is Roland Barthes' for whom there is "no transparent 'innocent' window on to "reality"' (119) - as we may say that Laugier' frontispiece "presumes" to be. Fixed in popula hought, for example, is the (mistaken) "presumption" that the pitched roof is the "truthful" image of home/reality.

11. "The primitive hut ... is no incidental concern of theorists, no casual ingredient of myth or ritual. The return to origins always implies a rethinking of what you do customarily, a recall of the natura or even divinel sanction for your repeating them for a season" (Rykwert 192).

12. a) Rykwert 45; McClung 120 (According to McClung, while the precise source of this goddess Architectura is unclear it was common for deities - neoplatonic abstractions with no history - to be invented in the Renaissance. McClung points to Ben Jonson's masque, Cbloridia, 1631, in which "Architecture" personified makes a fleeting appearance [only to deliver the droll one-liner: "Architecture will take you higher."): Middleton and Watkin 21 (This is enigmatic: if it is not the non-existent muse of architecture, which muse then?). b) The matter of weman's gesture is also subject to speculation so, too, is the significance of Cupid which McClung [in personal correspondence] conjec tures to be "either mankind in its infancy" or "some sort of guiding or inspirational spirit for mankind"). Is the woman's pointing a gesture of declaration or creation? We may speculate that if it is one of declaration then it implies that the hut had an existence prior to the scene depicted here (i.e., it "evolved" from Nature, with or without man's help); that it had an origin separate from the goddess who, upon arriving on the scene, now canonizes it or otherwise proclaim its authority and authenticity. If, on the othe hand, the gesture is one of creation, then this is the moment of the hut's appearing; it was re ceived by man intact, and thus the relationship between the woman and the hut is one of greater original interdependence and ontological impo (i.e., architecture sprung directly and instananeously, in this form, from the mind of the goddess without whom it could not exist). In both "readings" we may see the gesture as the symbolic act of commencement which signifies the break from time immemorial to time memorial (n. 13)

13. Larousse World Mythology, ed. Pierre Grimal (New York: Gallery Books, 1989), 103. The passage implies the etymological relation between memory and monument " "the finest monument a man can have is the memory he leaves behind him." Alberti [Franco Borsi, Leon Battista Alberti (New York: Harper \& Row, 1977), 17]), reminding us of architecture's inherent memorial function as historian or cultural record-keeper (n.3)

14. Encyclopaedia Britannica, 15th ed., s.v. "myth and mythology."

5. Michael Stapleton, A Dictionary of Greek and Roman Mythology (New York: Bell Publishing Company, 1978), 141.

16. On the idea of resistance to the fine arts and the gap between their classical theory and practice see Frank P. Chambers, Cycles of Taste: An Unacknowledged Problem in Ancient Art and Criticism (Cambridge: Harvard University Press, 1928); and McClung 47. But we may speculate that perhaps the fine arts did not require the Muses as reminders. The Muses were principally assigned to what we may say are the arts which, prior to the invention of writing, if not the printing press, were ephemeral - that is, those that required memorization for their presence and perpetuation; this as opposed to architecture painting, and sculpture which we might say are the arts in which memory is immanent - that is, which, due to the presence of an artifact, canno be forgotten and are thus the very manifestation of Mnemosyne/Memory.

17. Heinrich Wölfflin writes of the "peculia character of the art of building as compared with all the other arts which, proceeding from it, have gradually quite emancipated themselves." (Principles of Art History: The Problem of the Development of Style in Later Art, trans. M.D. Hottinger [New York: Dover Publications, Inc. 1950], 233). While architecture generally has been viewed as the art which includes the others, and not vice versa, the status of architecture has been subject to debate (n. 16). (See Rosanna Liebman, Modulus 18 [Charlottesville: The University of Virginia School of Architecture, 1987], intro.). Alberti especially prized painting, calling it "the mistress of the arts," whereof all beauty is born (Borsi 11): but from this we might infer the reality of there being a conceptual distinction between the idea of status and the idea of sum or origin. Mario Praz, in contemplating "the parallel between literature and the visual [i.e. fine] arts," refers to "the idea of the sister arts," among which he includes architecture, he writes that this idea "has been so rooted in men's minds since times of remote antiquity [n. 16!] that there must be in it something deeper than an idle speculation, something tantalizing and refusing to be lightly dismissed, like all problems of origins" (3). Liebman echoes Alberti when she suggests that architecture might legitimately be the "synthesis of the arts;" nevertheless, she, like Praz, still refers architecture as a sister art, which is illustrative of the more than rhetorical problem of architecture's identity as unique among the arts vis-d-d-vis its proper kinship relationship and status.

18. Mircea Eliade, The Sacred and the Profane: The Nature of Religion, trans. Willard R. Trask (New York: Harcourt Brace and World, 1959; rpt. Harcourt Brace Jovanovich, s.d.), 21.

19. Mnemosyne's tripartite knowledge is transferred to the human and literary realms with Memory serving as a corrective device, as Saint Augustine's paradigmatic Confessions demonstrates, in which Memory recalls to the sinner the errors of the past, thereby enabling im to correct the present, and redirect (remember) his future action

20. In "Architecture and Memory," Via 8: Architecture and Literature (New York: Rizzoli, 1986), 88-95, Umberto Eco notes the development of the idea of the "Temple as book." He briefly recounts the origin myth of the invention of writing which was considered to be the death of memory because "it will allow men to remember without having to use memory ever again" (89). While writing came first to usurp the idea of memory and ultimately architecture as the primary chronicle of memory (n. 3), nevertheless, "in modern time (as in ancient times) architecture superintends the construction of containers for the documents that represent the memory of a civilization: the library, the archive, the museum" (89). Architec ture memorializes (memori-alizes) the Muses through museums (muse-ums)

21. Roger Hinks, Mytb and Allegory in Ancient Ar (London: The Warburg Institute, 1939), 97.

22. "Because the interpretation of a work of art consists of two elements, the original one supplied by the artist of the past and the one which is superimposed by the later interpreter, one must wait until the latter element also belongs to the past in order to see it peep through, just as would happen with a palimpsest or a manuscript written in sympathetic ink" (Praz 34).

FIGURE CREDITS: 1. Laugier, op. cit.; 2. Watercolor drawing by the author $3,6,7,8$. Photographs by William Taylor; 4. Roman relief; Stapleton, op. cit. 5. Rykwert, op. cit.; 9. F. Schellenberg, engraving, 1786; Werner Oechslin, "Architecture and Alphabet," Via 8: Architecture and Literature (New York: Rizzoli, 1986); 10. Monuments of Egypt: The Napoleonic Edition, eds. Charles Coulston Gillispie and Miche Dewachter (Princeton: Princeton Architectural Press, 1987), from Pl. 37, A. Vol. II; 11. Drawing by the author 